The findings in this report are not to be construed as an official Department of the Army position unless so designated by other authorized documents. 


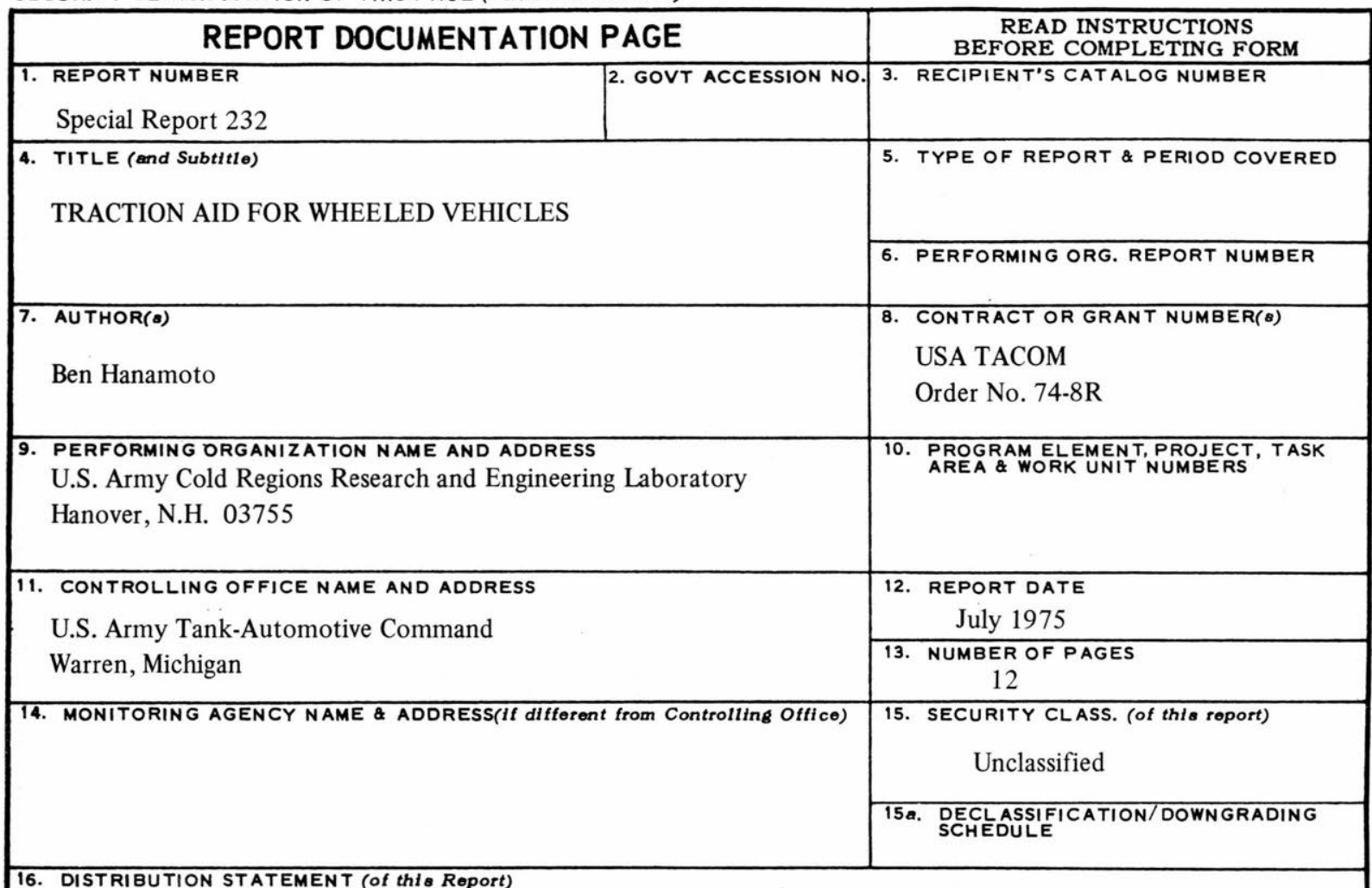

16. DISTRIBUTION STATEMENT (of this Report)

Approved for public release; distribution unlimited.

17. DISTRIBUTION STATEMENT (of the abstract ontered in Block 20, if different from Report)

18. SUPPLEMENTARY NOTES

19. KEY WORDS (Continue on reverse side if necessary and identify by block number)

Ground vehicles Traction

Mobility Vehicles

Operation Vehicle tracks

Tire chains Wheels

Tracked vehicles

20. ABSTRACT (Continue an roverso stich if mecoseary and tdentify by block number)

Performance tests with the Tyr-Trac traction aid device for wheeled vehicles had been conducted in Alaskan snow, and the results were so encouraging that further testing of the device was requested. In comparison to tire chains, the Tyr-Trac out-performed chains in all areas of operation: slope climbing, snow drifts and deep snow conditions. Additional tests were conducted in northern Michigan, comparing the drawbar pull-slip performance of an M35-A2 $2 \frac{1}{2}$-ton, $6 \times 6$ truck equipped with the Tyr-Trac, tire chains and with standard military tires at an inflation pressure of 15 psi. The results of these tests in no way duplicate the Alaskan results. Traction aids were of no use in snow deeper than 20 inches. Tests could be conducted only by reducing the snow cover to a depth of 12 to 17 inches. 


\section{Abstract (cont'd)}

Under these conditions both Tyr-Trac and chains performed equally, with a drawbar pull to weight ratio, $D B P / W$, equal to about 0.10 . If traction aids were to be used in shallower snow, tire chains would be preferred over the Tyr-Trac for these reasons: less weight and bulk for more convenient on-board stowage, more economical, and easier installation and removal in the field. 


\section{PREFACE}

This report was prepared by Ben Hanamoto, Mechanical Engineer, of the Applied Research Branch, Experimental Engineering Division, U.S. Army Cold Regions Research and Engineering Laboratory. The work was conducted for the Engineering Science Division, U.S. Army TankAutomotive Command, Warren, Michigan, under Order No. 74-8R.

Support for the project was provided by personnel of USA CRREL, USA TACOM, and the Keweenaw Field Station, Houghton, Michigan, operated by the Michigan Technological University. Special thanks are extended to T. Czako and M. Jefsen of USA TACOM; J. Stephan, formerly of USA CRREL; and Dr. R.A. Liston, J. Butula, C. Dimmer, G. Goodreau, A. Hauswirth and L. Zenner of the Keweenaw Field Station. Dr. W. Harrison and G. Abele technically reviewed this report.

The contents of this report are not to be used for advertising, publication or promotional purposes. Citation of trade names does not constitute an official endorsement or approval of the use of such commercial products. 


\title{
TRACTION AID FOR WHEELED VEHICLES
}

\author{
Ben Hanamoto \\ INTRODUCTION
}

The objective of these tests was to evaluate the Tyr-Trac, a mobility or traction aid for wheeled vehicles operating in snow. The Tyr-Trac, a track-over-wheels device, was produced in the early forties and was reportedly used in the swamps of the southern states. The tracks are not being produced now and at present there is no known source for procurement of the item.

Various track-over-wheels traction aids have been evaluated in the past but none have been successful enough for even limited use. Factors such as failures and low durability, track slippage on the wheels, and track throwing have not been offset by any marked improvement in mobility over adverse terrain. Another drawback was that the high weight and volume of the tracks took up the payload when the tracks were not in use. In addition, mounting of the device in the field required much time and effort.

Interest was again raised by the report of Lt. L.T. Messenger on his field tests of the Tyr-Trac in deep snow.* His tests were conducted in snow to compare the performance of an M34-A2 two-and-one-half ton dump truck equipped with chains and with the tracks in an effort to find a better traction aid than tire chains for wheeled vehicles. His requirements for the test included:

1. No moditication to the vehicle.

2. Ability to travel at least $15 \mathrm{mph}$ cross-country.

3. Low maintenance.

4. Easy installation (no more difficult than mounting tire chains).

Messenger reports that "The track truck met or exceeded every criterion specified in this feasibility study." Some maximum conditions encountered were also listed:
1. Snow depth
54 in.
2. Snowdrift 60 in.
3. Slope $\quad 46 \%$
4. Speed in snow $25 \mathrm{mph}$
5. Speed on road $15 \mathrm{mph}$

The test results showed that the tracked truck performed much better than an identical truck equipped with chains, which bogged down while trying to leave the road and could not follow in the trail left by the tracked truck. These results, to say the least, are very impressive. In fact, the quoted results of the speed and slope climbing tests exceed the performance of a low ground pressure tracked vehicle, the M-29-C Weasel. These results renewed interest in the track-over-tire type of mobility aid and led to further testing of the Tyr-Trac.

${ }^{*}$ Messenger, Leroy T. (1973) Tracks mounted on the duals of a two-and-one-half ton truck. U.S. Army, Alaska, 172nd Arctic Light Infantry Brigade, Headquarters 4th Battalion, 9th Infantry, APO Seattle 98731. 


\section{TESTING}

The tests were conducted adjacent to the Keweenaw Field Station located at the Houghton County Airport between Calumet and Houghton, Michigan. The Field Station is operated for the U.S. Army Tank-Automotive Command by the Michigan Technological University. Snow tests were conducted during the winters of 1974 and 1975. During the summer of 1974, additional tests were conducted in stamp sand, the frictional, coarsegrained remains of a copper ore processing operation found near the village of Gay, approximately 15 miles east of the station on the Lake Superior shore.

The Tyr-Tracs, weighing $450 \mathrm{lb}$ each, were mounted on the rear axles of the dualwheeled M-35-A2, six-by-six, two-and-one-half ton truck (Fig. 1). The test vehicle was also operated with tire chains mounted on all wheels and with no traction aids on the tires. No chains were used on the front tires when the tracks were mounted on the rear. The device was mounted inside a garage with a hydraulic floor jack and high pressure air available. The tires were deflated, the tracks installed and the tires reinflated. Under these conditions installation took a two-man crew about 2 hours; installation of the same tracks by a two-man crew in the field would require more time and effort.

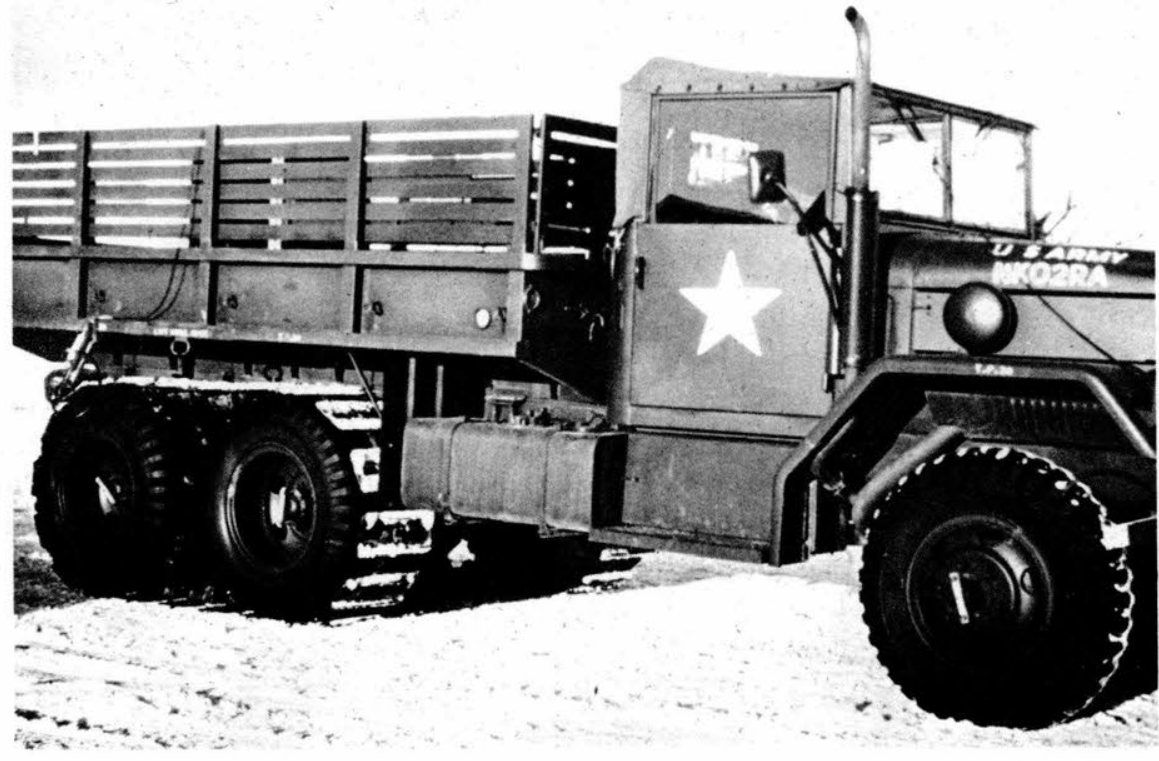

Figure 1. Tyr-Trac mounted on the M35-A2, 6x6 21/2-ton truck.

The winter tests were conducted in an open field adjacent to the Field Station complex. Level ground snow depths varied from 21 to $30 \mathrm{in.}$. A plowed roadway led to the test area. In attempting to move from the road onto the test area for the first test runs in 1974, the test vehicle with tracks became immobilized. Since the track tension had been improperly set, one track was thrown off the wheels during the attempt to back out.* The test vehicle, with or without tracks or chains, could not cope with the snow depth of about $2 \mathrm{ft}$ or more.

To allow the tests to be conducted, the snow depth was reduced in increments until the test vehicle could propel itself through the test course. The ' 74 tests required the removal of about half the original cover, leaving a depth of 12 to $17 \mathrm{in}$. The ' 75 test course was modified so that only 13 to 15 in. of the original cover remained. The snow cover was reduced using a D-7 bulldozer, dozing first to remove the snow and then backblading to level the surface. It was realized that the modified test course in no way resembled a naturally occurring snow cover, but the justification for its use was that the test vehicle would be operating under identical conditions in all three modes of operation, so that comparison of results would be valid.

*Immobilization also occurred with properly tensioned tracks in the winter ' 75 tests. 
The comparative performance test measured the drawbar pull-slip characteristics of the test vehicle equipped with the Tyr-Trac, with tire chains, and with no traction aids but with tire pressure reduced to $15 \mathrm{psi}$, the recommended cross-country inflation pressure. The instrumentation for the test included: 1) tachometer generators mounted on both front wheels and on each of the four rear dual wheels to measure theoretical wheel speed, 2) a strain gauge load cell in the cable connecting the test and load vehicle, 3) a hydraulic load cell in the connecting cable with a dial indicator at the driver's position in the load vehicle to assist him in applying constant braking loads, 4) a drum and line fifth wheel system attached to the load vehicle with the end of the line anchored and the speed of the line played off the drum measuring the actual vehicle speed. An eight channel recording system and a gasoline-powered AC generator, both mounted in the load vehicle, completed the instrumentation set-up.

The test vehicle was operated with the transmission in the lowest gear and with the transfer case in low range. The drawbar loads were varied so that the entire slip range could be covered, from very low to $100 \%$ slip. Initially, no load was applied so that the engine of the test vehicle reached the selected operating speed $(1800 \mathrm{rpm})$. Then loads were applied in increments, each held as constant as possible to obtain a representative slip value for this load. The hydraulic load cell indicator aided the load vehicle driver in maintaining constant loads. The loads were increased up to the stall or $100 \%$ slip condition. Single test lanes of about $300 \mathrm{ft}$ were prepared and six to eight repetitive runs were conducted in a lane. After the area in the test lane had been used, a second test lane was prepared with the D-7 dozer. Each test lane was prepared just prior to test runs in an attempt to maintain similar test lane conditions.

\section{TEST RESULTS AND DISCUSSION}

\section{Winter tests}

Self-propelled runs were conducted in the prepared test lanes to observe the speed and the ease or difficulty with which the test vehicle traversed the test area in a straight line course. These tests could hardly be called a success with any of the three vehicle conditions: chains, tracks or no aids. In all three cases, total immobilization requiring recovery occurred only a few times but forward movement was limited to 20 or $30 \mathrm{ft}$ before the vehicle bogged down. After backing up, the vehicle was again able to travel a short distance forward before it bogged down again. This back and forth sequence was repeatable so that forward progress was made but at a very slow rate. The only comment that can be made about the self-propelled test is that although total immobilization might not occur, movement through this snow cover of 12 to $17 \mathrm{in}$. for any distance would be far too timeconsuming.

The drawbar pull-slip tests were also conducted with the test vehicle equipped with no aids, chains and tracks. The snow strength conditions of the winter ' 74 tests permitted testing of all three cases, whereas tests conducted in ' 75 were limited to the tracks alone. In the ' 75 tests, movement with tracks was marginal, with four out of the fourteen tests run with no load (the vehicle only being able to propel itself). The test vehicle with chains could barely operate in the self-propelled mode so that attempting a drawbar pull test would have been a waste of effort. With plain tires and no aids, movement would have been impossible. The snow densities for these two test conditions are shown in Tables I and II. A wet snow condition existed in ' 74 with an almost saturated, wet layer at ground level.

The results of the winter ' 74 tests are shown in Figures 2-4. Figure 5 shows the results of the winter ' 75 tests. Allowing for the scatter of the data, no marked difference in performance was measured between the track- and chain-equipped vehicle. The slip range of interest is between 10 and $40 \%$, the range of most efficient operation. At the higher slips, the test vehicle was digging down, and at times the wheels were down to the ground 
Table I. Snow density profile, 7 Mar 1974.

Time 1140, sky cloudy, surface graded, air temperature $-9^{\circ} \mathrm{C}$. Measurements made 2,7 and 13 in. from top.

\begin{tabular}{|c|c|c|c|c|c|c|}
\hline & Description & Grain & Wetness & Hardness & Density & Temp \\
\hline & & Dd & & & 0.230 & $-2^{\circ} \mathrm{C}$ \\
\hline $16 \mathrm{in.}$ & Loose & Dd & & & 0.420 & $-1^{\circ} \mathrm{C}$ \\
\hline & & & Wet & & 0.435 & 0 \\
\hline
\end{tabular}

Table II. Snow density profile, 20 Feb 1975.

Time 1020, sky cloudy, surface graded, air temperature $-9^{\circ} \mathrm{C}$. Measurements made 6,12 and 18 in. from top. Shear strength: $c=0.5 \mathrm{psi}, \phi=11^{\circ}$.

\begin{tabular}{|c|c|c|c|c|c|}
\hline Description & Grain & Wetness & Hardness & Density & Temp \\
\hline & & Dry & & 0.339 & $-3^{\circ} \mathrm{C}$ \\
\hline & & Moist & & 0.398 & $-5^{\circ} \mathrm{C}$ \\
\hline & & Wet & & 0.372 & $-1.5^{\circ} \mathrm{C}$ \\
\hline
\end{tabular}

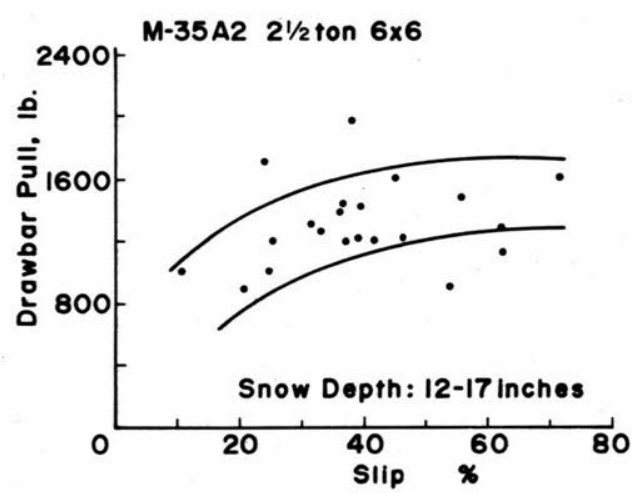

Figure 2. Drawbar pull-slip results with Tyr-Tracs, winter 1974.

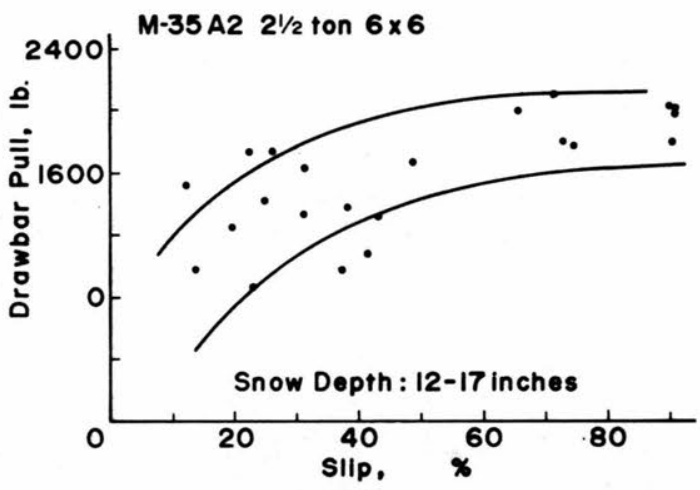

Figure 3. Drawbar pull-slip results with chains, winter 1974.

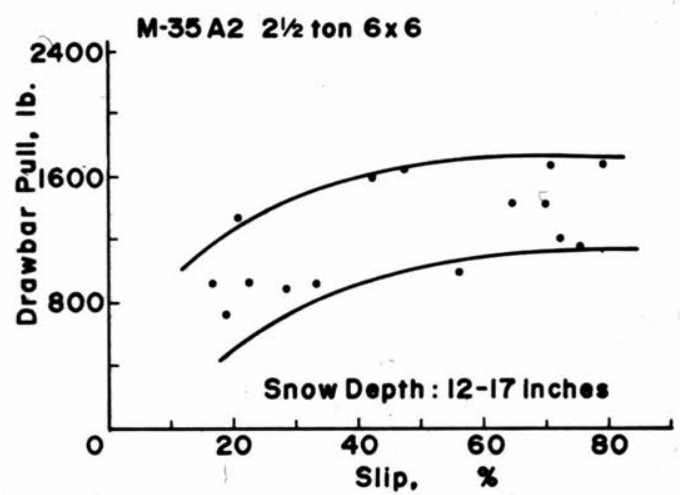

Figure 4. Drawbar pull-slip results with standard military tires (no aids), winter 1974. 


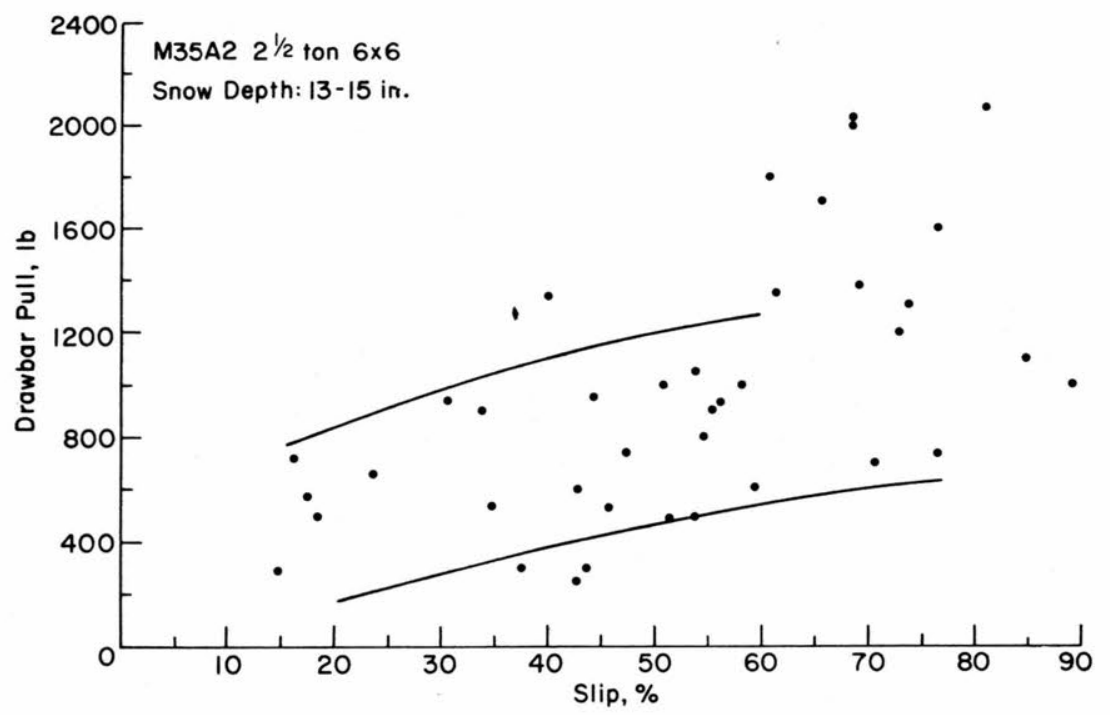

Figure 5. Drawbar pull-slip results with Tyr-Tracs, winter 1975.

surface. The performance of the test vehicle with no aids was lower than that with chains or tracks. Winter ' 75 results, where only the tracks were tested, show the marginal operating condition that existed. In the most efficient slip range of operation the pulls were low, and as mentioned earlier, no loads could be applied for some of the runs. At the higher slips, some of the high readings resulted when traction was provided by the soil surface rather than the snow cover.

The results of these tests have shown that traction aids for wheeled vehicles are not the answer for operation through deep snow. With total vehicle weights of over $14,000 \mathrm{lb}$ with tracks attached and about $13,400 \mathrm{lb}$ with chains, drawbar pull in the 1000-lb range is marginal operation, and these are values with the snow cover reduced to between 12 and 17 in., the lower depth range for deep snow conditions. Judging from the performance of the Tyr-Trac during these tests, the performance reported by Messenger (op. cit.) seems high. Cross-country speeds of $15 \mathrm{mph}$ and maximum "through" snow speeds of $25 \mathrm{mph}$ cannot be matched by "over" snow low ground pressure tracked vehicles which can average $5-7 \mathrm{mph}$ cross-country and less than $15 \mathrm{mph}$ sustained maximum over snow.

\section{Summer tests}

The summer tests with the same test vehicle equipped with tracks, chains and with no aids were conducted to determine the effects of traction aids in another material, stamp sand, frictional like snow but with quite different bearing strength and compressive qualities. The test area, with straight courses of up to a mile, was processed by a disc harrow with a surface leveler towed behind it. A partial view of the test course and the load and instrument carrying vehicle are shown in Figure 6. Two M35-A2 trucks were available so that load and test vehicles were interchanged, chains mounted on one and tracks on the other, eliminating the time-consuming installation and removal of the traction aids. The last test to be conducted was with no aids and this entailed only the removal of the chains. The same instrumentation was used as in the snow tests. Runs started at a light load and low slip and the load was increased in increments to the stall or $100 \%$ slip point. A single test run required about $300 \mathrm{ft}$, and for each of the three test conditions a minimum of ten runs were conducted. The long test lane eliminated the need for the cumbersome turning or reprocessing that was required when working in a more confined area. The in-line, straight ahead test reduced the actual testing time by about half. 


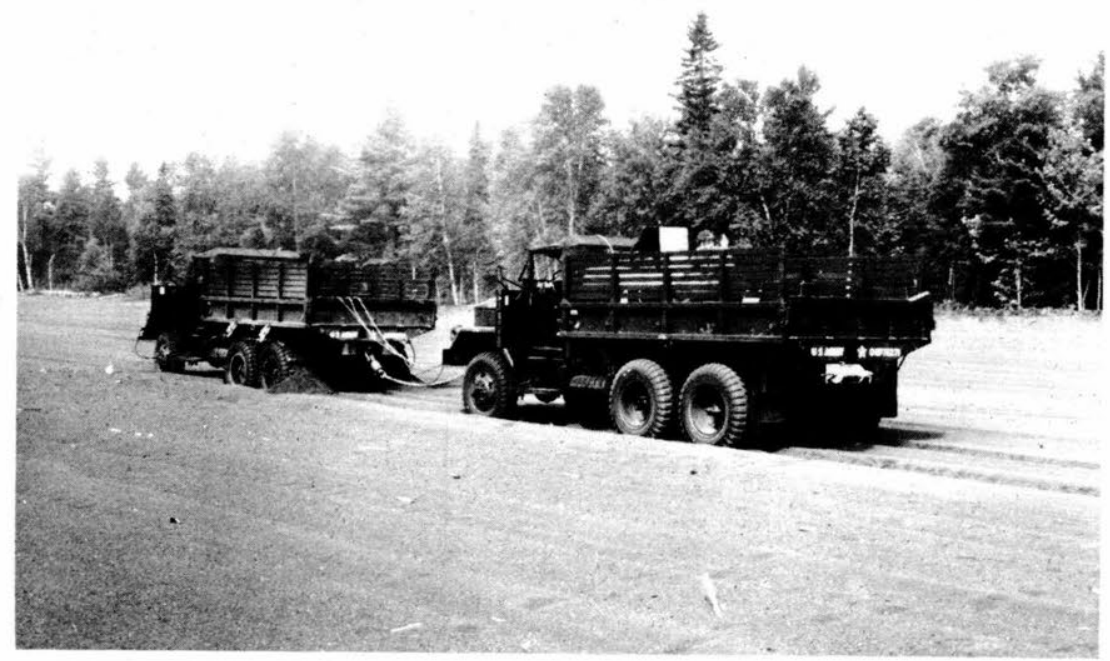

Figure 6. Stamp sand test course, load: instrument-carrying vehicle.

The test results are plotted in Figures 7-9. The graphs for each of the test conditions are plotted as drawbar pull versus slip and also as efficiency versus slip, a term mentioned earlier. The efficiency is defined as:

$$
(\mathrm{DBP} / W)\left(1-i_{0}\right)
$$

where $\mathrm{DBP}=$ drawbar pull, $\mathrm{lb}$

$W=$ vehicle weight, $\mathrm{lb}$

$i_{0}=$ slip.
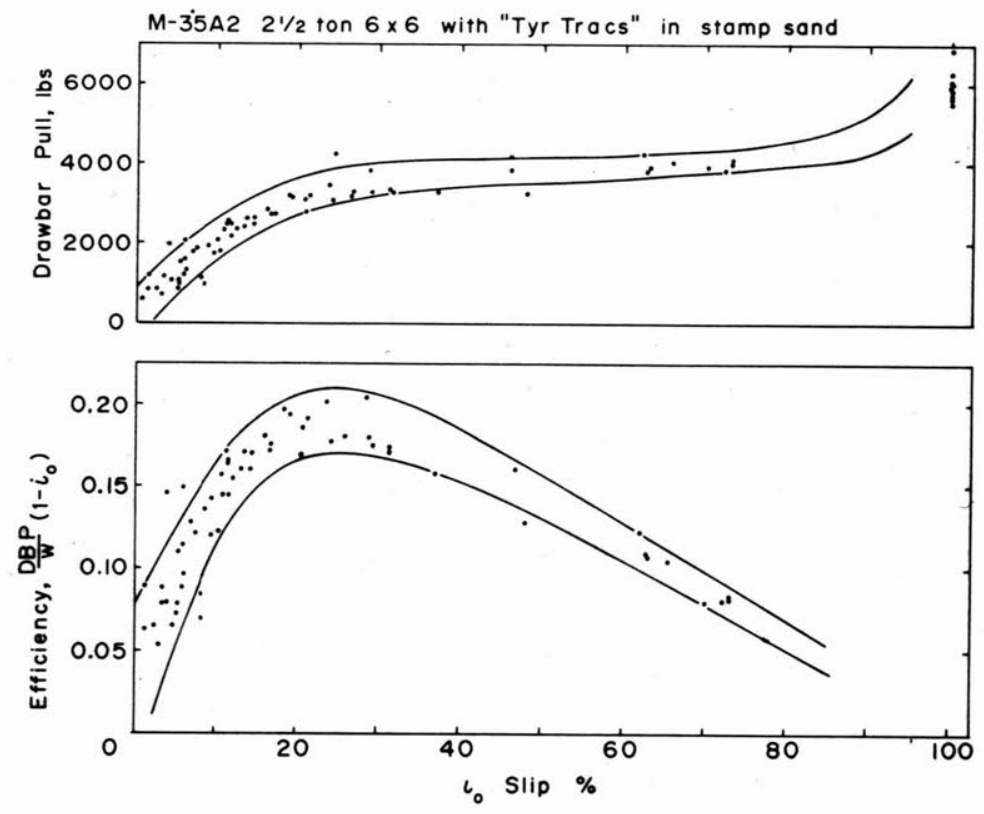

Figure 7. Test results in stamp sand, Tyr-Tracs. 

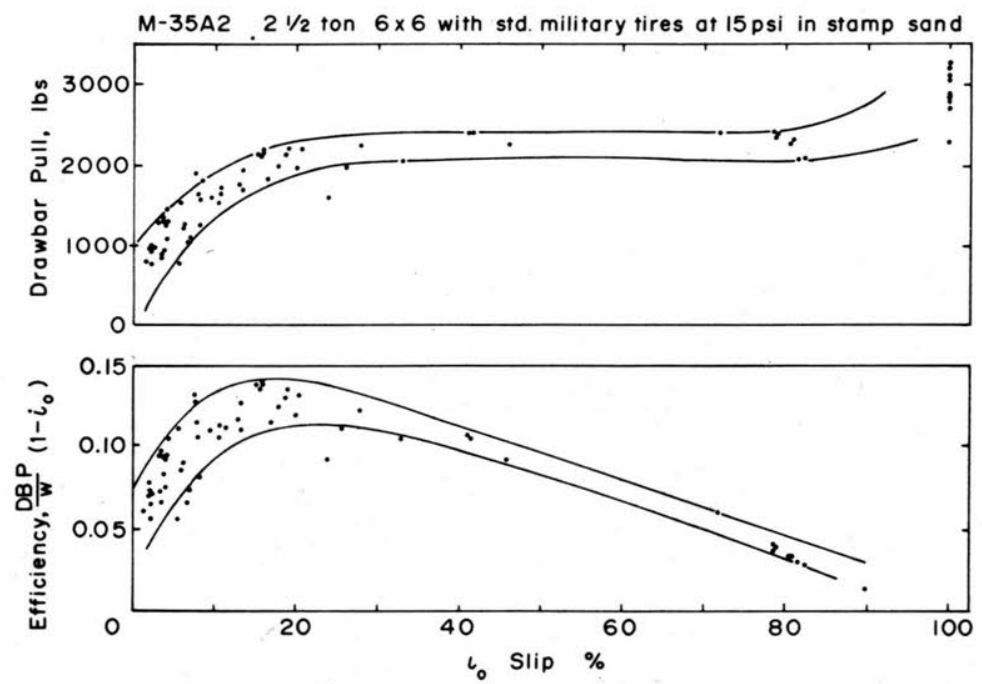

Figure 8. Test results in stamp sand, standard military tires at 15 psi.
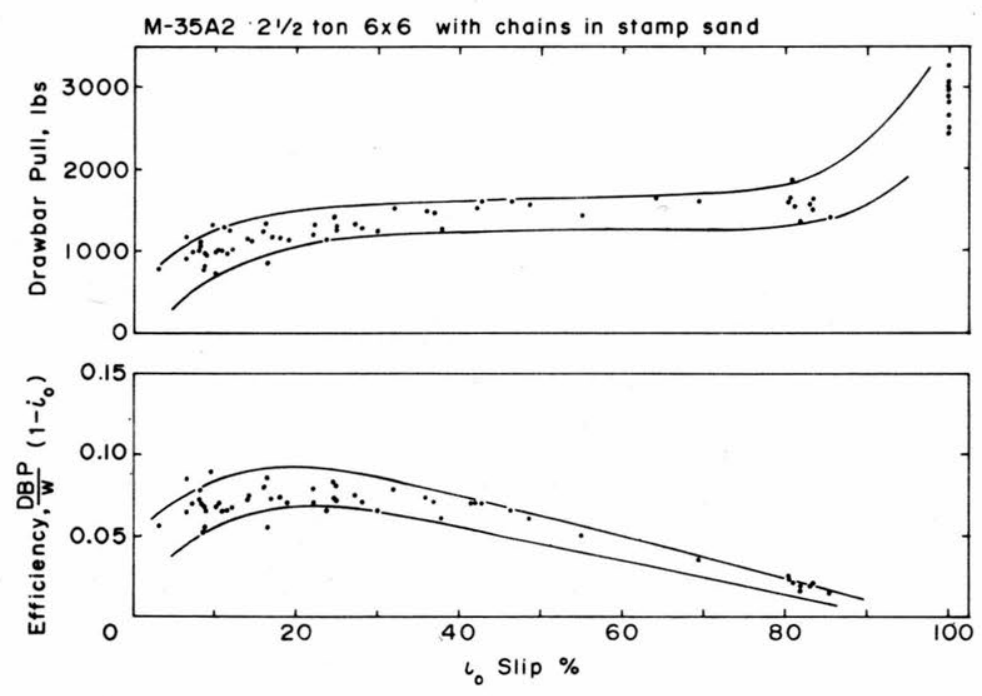

Figure 9. Test results in stamp sand, tire chains.

The ranking of performance was found to be Tyr-Trac first, the tires at 15-psi inflation pressure with no aids second, and the tires with chains last. Quite a variation in pull resulted: $3400 \mathrm{lb}$ with the tracks, $2100 \mathrm{lb}$ with the 15 -psi tires, and $1250 \mathrm{lb}$ with tire chains. These values are at the most efficient slip range, between 20 and $30 \%$ slip. In terms of the ratio $\mathrm{DBP} / W$, for the Tyr-Trac the ratio was 0.24 , for the 15 -psi tires it was 0.16 , and for tires with chains it was 0.093 . In comparison, two track-laying vehicles tested at the same site produced these values: the M29C Weasel 0.64 and the M-113 APC 0.37. The advantage of tracks as compared to wheels is obvious, especially for the low ground pressure Weasel. The better performance of the Tyr-Trac in sand could be attributed to the lower ground pressure for the rear contact area, the tracks bridging the gap between the two rear axles and reducing the ground contact pressure by a factor of two or more. The low pressure tires also had a reduced contact pressure when compared to the tires with chains but one feature of chains, detrimental to operation in frictional materials, is their aggressiveness, which results in digging-in and excessive sinkage. More sinkage means more motion resistance and a reduction in drawbar pull. Variations in sinkage can be seen in 
Figures 10 and 11 between the low pressure tire and the tire with chains, both taken at the termination of their runs, the stall or $100 \%$ slip point. In contrast to stamp sand, the weak bearing strength and the compressibility characteristics of snow combined to allow sinkage so that neither traction aid was of much use; the motion resistance was so great that no differences could be noted between these devices.

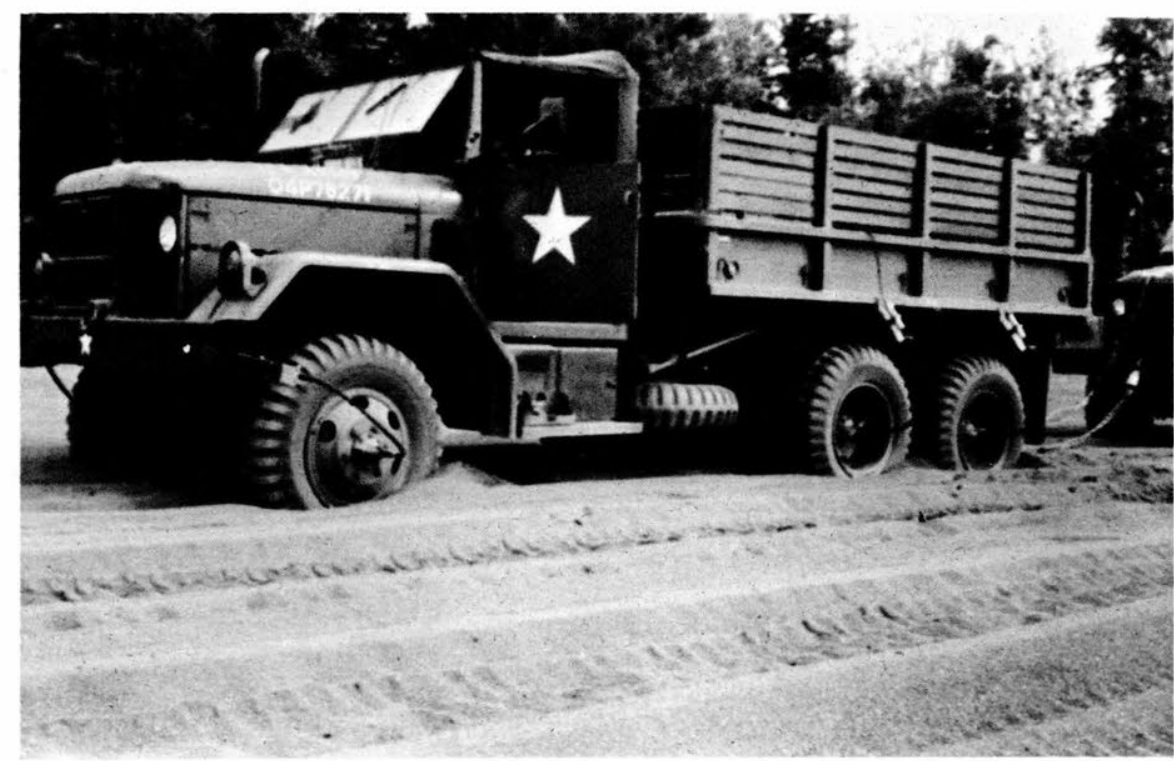

Figure 10. Wheel sinkage, 15-psi tires.

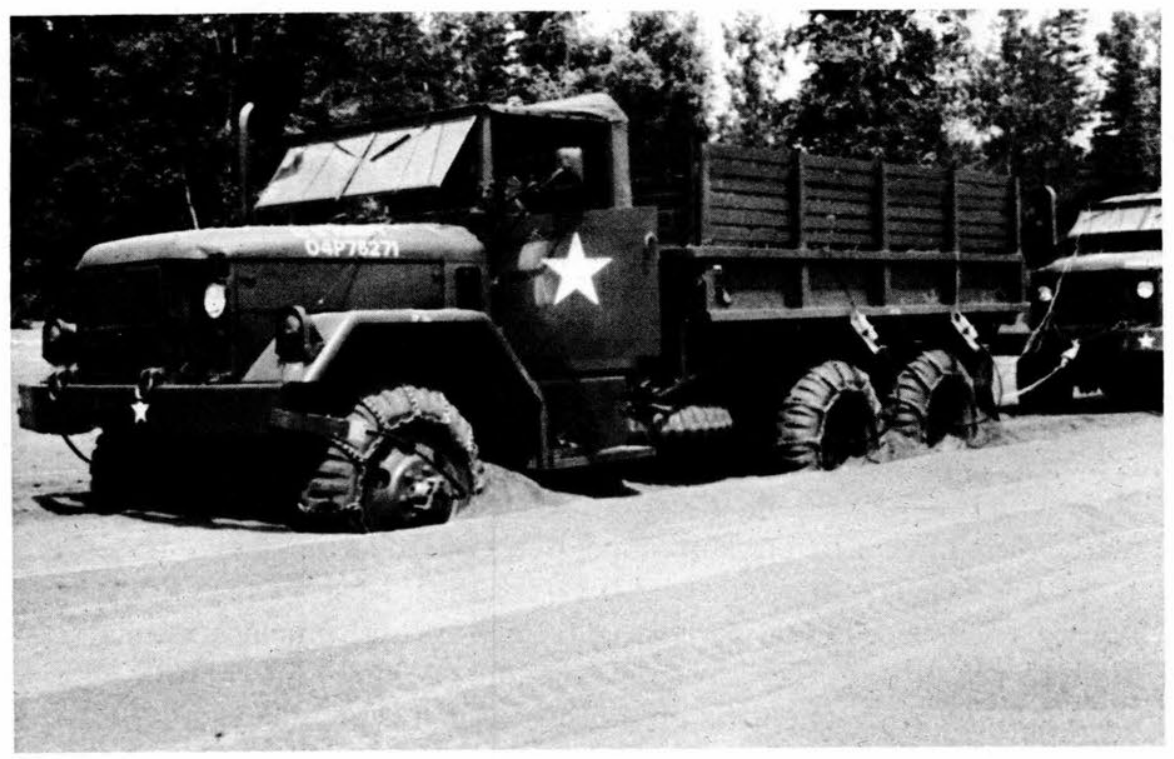

Figure 11. Wheel sinkage, tires with chains. 


\section{CONCLUSIONS}

The use of the Tyr-Trac as a traction aid in deep snow produced no improvement in performance of the $21 / 2$-ton M35 A2 truck compared to the same truck equipped with tire chains. In soils with greater bearing strengths than snow, the Tyr-Tracs reduced the ground contact pressure, which reduced sinkage, so that the Tyr-Tracs performed much better than chains. If deep snow is defined as 20 in. or more, then traction aids were of no value, since immobilization occurred whether aids were used or not. In snow less than 12 in. deep, where performance might be improved by the use of traction aids, tire chains have advantages over the tracks: they have less weight and bulk for more convenient onboard storage, are cheaper, and are easier to install and remove in the field. 